Review began 02/25/2022 Review ended 03/04/2022 Published 03/07/2022

๑) Copyright 2022

Wu et al. This is an open access article distributed under the terms of the Creative Commons Attribution License CC-BY 4.0. which permits unrestricted use, distribution, and reproduction in any medium, provided the original author and source are credited.

\section{A Rare Case of Splenic and Pulmonary Metastases From Renal Cell Carcinoma}

\author{
Kathie $\mathrm{Wu}^{1}$, Delnaz Bakht ${ }^{2}$, Priyanka Pathak ${ }^{2}$, Nadia Ramdin ${ }^{2}$ \\ 1. Internal Medicine, Geisinger Medical Center, Danville, USA 2. Hematology/Oncology, Geisinger Medical Center, \\ Danville, USA \\ Corresponding author: Kathie Wu, kwu1@geisinger.edu
}

\begin{abstract}
Renal cell carcinoma commonly spreads to the lungs, bones, and liver, but splenic involvement has been rare. When metastasis does occur, patients are usually asymptomatic but may present with weight loss, fatigue, or abdominal pain. We present a case of a patient who had known renal cell cancer status post-total nephrectomy who, due to COVID, had delayed surveillance scans and was found to have a recurrent mass in the nephrectomy bed with splenic and pulmonary metastasis.
\end{abstract}

Categories: Oncology

Keywords: pulmonary metastasis, nephrectomy, covid-19, splenic metastasis, renal cell carcinoma

\section{Introduction}

Renal cell carcinoma accounts for more than $90 \%$ of all cancers in the kidney and has been the most lethal of urologic malignancies [1]. Localized disease can be successfully managed with resection, but metastatic disease can be resistant to conventional chemotherapy, leading to the use of targeted therapies that inhibit vascular endothelial growth factor and receptor. Typical sites of spread in cases of metastatic disease include the lungs, bones, and liver. Even after primary nephrectomy, late metastases can be found up to 20 years after initial surgery and recurs in $20 \%$ to $40 \%$ of patients with previously localized disease [1-2]. Follow-up depends on the stage of disease but typically includes abdominal CT or MRI annually [3].

\section{Case Presentation}

A 72-year-old female with a past medical history of known renal cell cancer presented to office with concerns of left-sided back pain since several months. Her history was significant for a left nephrectomy a year prior for renal cell carcinoma for which she was due for a follow-up scan a year later. Due to COVID-19, her surveillance scans were delayed by several months. When they were obtained, the scans showed pulmonary nodules, which were biopsied and consistent with metastatic renal cell carcinoma for which she was started on nivolumab. A few months later, the patient presented to the office with new-onset back pain with radiation down the left leg worsening over the past several months. Given her history of metastasis, these symptoms were concerning for disease progression and she was sent for CT imaging of the chest, abdomen, and pelvis. Imaging showed a recurrent soft tissue mass in the left nephrectomy bed with invasion into the splenic vein and splenic arteries (Figure $1 \mathrm{~A}$ ) resulting in splenic infarct as well as multiple nodules and masses in bilateral lungs (Figure $1 B$ ) that increased in size, thus concerning for worsening metastatic tumor burden. Since her disease progressed despite being on nivolumab therapy and given the extent of her disease, the patient transitioned to palliative care and subsequently passed. 


\section{Cureus}
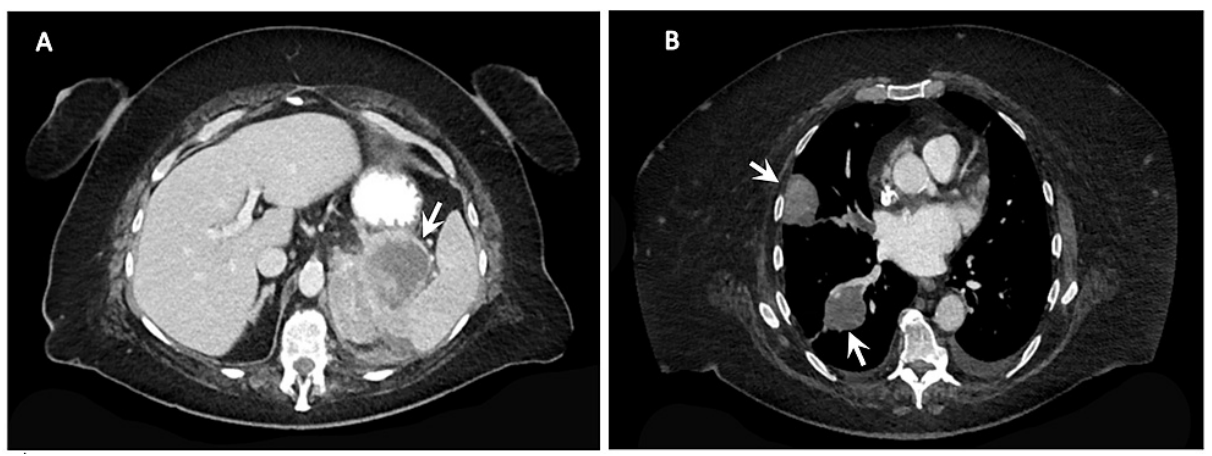

FIGURE 1: (A) Mass in the left nephrectomy bed with invasion into the splenic vasculature. (B) Presence of metastatic disease to the lungs.

$\mathrm{CT}$ of the chest, abdomen, and pelvis with contrast demonstrating metastatic spread of renal cell carcinoma into the left nephrectomy bed and splenic vasculature and spread into the lungs.

\section{Discussion}

Primary and metastatic diseases to the spleen are uncommon largely due to the anatomical and histological characteristics of the spleen. The sharp angle of the splenic artery within the celiac axis along with the pulsating contractions within the sinusoids in addition to the presence of immunological cells within the spleen have been theorized to limit metastatic spread [4-5]. An estimated 30\% of cases of renal cell carcinoma already have distant metastasis by the time of diagnosis, with common sites of spread to the lungs, bone, liver, and brain [6]. In these cases of metastatic spread, adjuvant therapy has only been shown to be effective in around $10 \%$ of patients [7]. However, in cases of metastasis to isolated organs, surgical resection may be performed with favorable prognosis [7].

Upon literature review, there are, to the best of our knowledge, less than 20 cases of splenic metastasis from renal cell carcinoma [4] (Table 1). In the reported cases, majority were from a left kidney primary, suggesting that there may be a degree of direct spread of tumor cells rather than hematogenous metastasis [4]. In total, $100 \%$ of patients underwent surgical resection, with two receiving adjuvant radiation or biologic therapy. All but two of the patients were alive at the time of publication, which again supports earlier surgical intervention especially in limited disease. Though rare, cases of splenic metastasis have been thought to be clinically underestimated when patients are asymptomatic. Therefore, we must rely on diagnostic imaging for surveillance as cases of renal cell metastasis can arise several years out from initial diagnosis, as seen in the literature review (Table 1). 


\section{Cureus}

\begin{tabular}{|c|c|c|c|c|c|}
\hline Author & Age/Sex & Primary (Kidney) & Time to Metastasis & Treatment & Outcome \\
\hline Strum, $1984[8]$ & $55 \mathrm{M}$ & Right & 264 months & Surgery and radiation & Deceased \\
\hline Ishida et al., 1997 [9] & $50 \mathrm{M}$ & Left & 84 months & Surgery & Alive \\
\hline latsuta et al., 2001 [10] & $69 \mathrm{M}$ & Left & 22 months & Surgery & Allve \\
\hline Kugel et al., 2003 [11] & $72 \mathrm{M}$ & Left & 24 months & Surgery & Deceased \\
\hline McGregor et al., 2003 [12] & $65 \mathrm{M}$ & Left & Synchronous & Surgery & Unknown \\
\hline lelpo et al., 2010 [5] & $68 \mathrm{M}$ & Left & 168 months & Surgery & Allve \\
\hline Moir et al., 2011 [13] & $70 \mathrm{~F}$ & Left & 11 months & Surgery & Alive \\
\hline Nunes et al., 2012 [14] & $55 \mathrm{~F}$ & Left & 60 months & Surgery & Alive \\
\hline Zhang et al., 2015 [15] & $67 \mathrm{M}$ & Left & 24 months & Surgery and radiation & Alive \\
\hline Grewal et al., 2016 [16] & $53 \mathrm{M}$ & Left & 2 months & Surgery and sunitinib & Alive \\
\hline Costantini et al., 2019 [17] & $41 \mathrm{M}$ & Right & 51 months & Surgery & Alive \\
\hline Dos Santos Romao et al., 2019 [4] & $48 \mathrm{M}$ & Left & 132 months & Surgery & Alive \\
\hline
\end{tabular}

TABLE 1: Cases of splenic metastasis originating from renal cell carcinoma in the literature.

\section{Conclusions}

There are reports of renal cell carcinoma metastases to the lung but limited reports of spread to the spleen, making this case rather unusual. Given the extent of her disease, surgical resection was not pursued and the patient ultimately decided to stop all immunotherapy with transition to comfort care. This case highlights the importance of timely surveillance scans as renal cell carcinoma may present years after initial tumor diagnosis. Prompt follow-up and early diagnosis may improve overall outcomes, while disease burden remains low.

\section{Additional Information \\ Disclosures}

Human subjects: Consent was obtained or waived by all participants in this study. Conflicts of interest: In compliance with the ICMJE uniform disclosure form, all authors declare the following: Payment/services info: All authors have declared that no financial support was received from any organization for the submitted work. Financial relationships: All authors have declared that they have no financial relationships at present or within the previous three years with any organizations that might have an interest in the submitted work. Other relationships: All authors have declared that there are no other relationships or activities that could appear to have influenced the submitted work.

\section{References}

1. Chin AI, Lam JS, Figlin RA, Belldegrun AS: Surveillance strategies for renal cell carcinoma patients following nephrectomy. Rev Urol. 2006, 8:1-7.

2. Bruckschen F, Gerharz CD, Sagir A: Renal cell carcinoma with unusual metachronous metastasis up to 22 years after nephrectomy: two case reports. J Med Case Rep. 2021, 15:490. 10.1186/s13256-021-03098-5

3. National Comprehensive Cancer Network - Home. (2022). Accessed: February 25, 2022: https://www.nccn.org/professionals/physician gls/pdf/kidney.pdf.

4. Dos Santos Romao D, Horvat N, Castro Gonçalves M, Shigueaki Abe E, Blanco Dumarco R, Cesar Cavalcante Viana P, Machado MC: Isolated splenic metastases from renal cell carcinoma 11 years after surgery . Case Rep Med. 2019, 2019:7480479. 10.1155/2019/7480479

5. Ielpo B, Mazzetti C, Venditti D, Buonomo O, Petrella G: A case of metachronous splenic metastasis from renal cell carcinoma after 14 years. Int J Surg. 2010, 8:353-5. 10.1016/j.ijsu.2010.04.006

6. Morgenstern L, Rosenberg J, Geller SA: Tumors of the spleen. World J Surg. 1985, 9:468-76. 10.1007/BF01655283

7. Lee SS, Morgenstern L, Phillips EH, Hiatt JR, Margulies DR: Splenectomy for splenic metastases: a changing clinical spectrum. Am Surg. 2000, 66:837-40.

8. Strum WB: Remote recurrence of renal cell carcinoma. Urology. 1984, 23:68-70. 10.1016/00904295(84)90181-x

9. Ishida H, Konno K, Ishida J, et al.: Isolated splenic metastases. J Ultrasound Med. 1997, 16:743-9. 10.7863/jum.1997.16.11.743 


\section{Cureus}

10. Tatsuta M, Shiozaki K, Masutani S, et al.: Splenic and pulmonary metastases from renal cell carcinoma: report of a case. Surg Today. 2001, 31:463-5. 10.1007/s005950170142

11. Kugel V, Dekel Y, Konichezky M, Baniel J, Livne PM, Koren R: Unusual splenic metastasis from renal cell carcinoma. A case report and review of the literature. Pathol Res Pract. 2003, 199:739-43. 10.1078/03440338-00490

12. McGregor DH, Wu Y, Weston AP, McAnaw MP, Bromfield C, Bhattatiry MM: Metastatic renal cell carcinoma of spleen diagnosed by fine-needle aspiration. Am J Med Sci. 2003, 326:51-4. 10.1097/00000441-20030700000008

13. Moir JA, Sen G, Saif R, Haugk B, French JJ: Isolated splenic metastasis from renal cell carcinoma: case report and review. Case Rep Gastroenterol. 2011, 5:166-71. 10.1159/000326963

14. Nunes TF, Szejnfeld D, Miiji LN, Goldman SM: Isolated metachronous splenic metastasis from renal cell carcinoma after 5 years. BMJ Case Rep. 2012, 2012:bcr2012006992. 10.1136/bcr-2012-006992

15. Zhang L, Pasquale D, Le M, Patel R, Mehdi S: Isolated splenic metastasis in a patient with two distinct genitourinary malignancies. J Community Support Oncol. 2015, 13:229-30. 10.12788/jcso.0143

16. Grewal SK, Doley RP, Roy K, et al.: Isolated splenic metastasis from clear cell renal carcinoma - a case report . Int J Surg Case Rep. 2016, 29:44-6. 10.1016/j.ijscr.2016.10.045

17. Costantini M, Tuderti G, Minisola F, et al.: Metachronous isolated splenic metastasis in a young patient with renal cell carcinoma: case report and literature review. Urology. 2019, 127:13-8.

10.1016/j.urology.2019.01.007 